\title{
OCORRÊNCIA DE CONTAMINAÇÃO EM FÍGADO, LÍNGUA E PULMÃO DE BOVINOS ABATIDOS SOB INSPEÇÃO FEDERAL NO MUNICIPIO DE ARAGUARI, MINAS GERAIS
}

\author{
OCCURRENCE OF CONTAMINATION IN LIVER, TONGUE AND LUNG OF \\ CATTLE SLAUGHTERED UNDER FEDERAL INSPECTION IN MUNICIPALITY \\ OF ARAGUARI, MINAS GERAIS STATE
}

R. F.VIEIRA ${ }^{1} *$, W. M. R. SOUSA ${ }^{1}$, K. F. LIMA ${ }^{1}$, D. P. NUNES ${ }^{2}$, R. Q. MOREIRA ${ }^{3}$

\begin{abstract}
RESUMO
Objetivou-se verificar a ocorrência de condenações, por contaminação, de fígado, língua e pulmão em um abatedouro-frigorífico com Serviço de Inspeção Federal (SIF) localizado no município de Araguari MG. Para isso foi feito um estudo retrospectivo dos casos de condenações por contaminação dos órgãos fígado, língua e pulmão de 71.765 bovinos abatidos em todo o ano de 2014. O levantamento dos dados foi feito a partir de todos os registros do Departamento de Inspeção Final (DIF) do abatedouro-frigorífico, contabilizando os números de lesões por mês, e posteriormente o total daquele ano. No total de 71.765 bovinos abatidos no período estudado, 357 animais (0,5\%), tiveram o fígado condenado por contaminação durante o processo de abate. Além disso, 832 animais $(1,16 \%)$ também foram condenados devido à contaminação da língua. E, referindo-se a pulmão, 5.376 animais abatidos $(7,5 \%)$ também sofreram condenação por efeitos que levaram a sua contaminação. Tais condenações aconteceram respeitando o artigo 165 do Regulamento da Inspeção Industrial e Sanitária de Produtos de Origem Animal (RIISPOA), que indica a condenação de carcaças ou de suas frações que se contaminarem por fezes durante a evisceração ou em qualquer outra fase do processo de abate, ou mesmo contato com os pisos ou de qualquer outra forma de contaminação, desde que não seja possível uma limpeza completa. Conclui-se que houve uma considerável condenação de pulmões, seguido pelos órgãos língua e fígado, em decorrência da contaminação durante o processo de abate de bovinos. Tal ocorrência representa não só prejuízos econômicos para a indústria de produtos cárneos, como também pode refletir numa redução das qualidades microbiológica, visual e organoléptica destes produtos ao consumidor, podendo até mesmo ser um risco à saúde pública.
\end{abstract}

PALAVRAS-CHAVE: ZOONOSE. SAÚDE PÚBLICA. ABATEDOURO. TOXINFECÇÃO ALIMENTAR. CONDENAÇÃO POST-MORTEM.

ÁREA TEMÁTICA: Higiene e Inspeção de Produtos de Origem Animal

\footnotetext{
${ }^{1}$ Graduandos em Medicina Veterinária pelo Instituto Master de Ensino Presidente Antônio Carlos - Araguari

${ }^{2}$ Médico Veterinário

${ }^{3}$ Professor de Citologia, Histologia e Embriologia e Histologia Especial no curso de Medicina Veterinária do Instituto Master de Ensino Presidente Antônio Carlos - Araguari; Doutorando em Ciências Veterinárias pela Universidade Federal de Uberlândia

E-mail para correspondência: rogersfv@hotmail.com
} 